Original Article

\title{
Hubungan Pola Makan Pasien CKD dengan Indeks Massa Tubuh (IMT) Pasien yang Menjalani Hemodialisa di RS Dik Pusdikkes Kodiklat AD
}

\author{
Devi Sukanti ${ }^{1}$, Bambang S. ${ }^{2}$, Sumedi W. ${ }^{3}$, \\ 1,2,3 Program Studi Ilmu Kesehatan \\ ${ }^{1,2,3}$ Sekolah Tinggi Ilmu Kesehatan Indonesia Maju \\ Jl. Harapan Nomor 50, Lenteng Agung-Jakarta Selatan 12610 \\ ${ }^{1,2,3}$ Email: devisukanti99@gmail.com ${ }^{1}$
}

\begin{abstract}
Introduction: Dietary factors or eating patterns can cause patients to experience anorexia so that it affects the body mass index measured by CKD patients (Susetyowati, 2014). Therefore, it is important to understand the research when studying the relationship between the diet of CKD patients and the body mass index of patients undergoing hemodialysis at the Dik Pusdikkes Hospital in 2021.

Objective: This study aims to determine how big the influence of the relationship between the diet of CKD patients and the body mass index of patients undergoing hemodialysis to improve the quality of life of CKD patients.

Method: The type of research used is quantitative research with a correlational design to determine whether there is a relationship between variables using experimental research. The population in this study that became the study population were all hemodialysis patients at the AD Pusdikkes Hospital. The sampling technique used was total sampling. The research instrument used is a questionnaire. The questionnaire is not standardized so that validity and reliability tests are carried out. In this study, the analysis used the chi-square test.

Results: the results of the chi-square test showed that the p-value $(0.028)<0.05$ then Ha was accepted or there was a relationship between the diet of CKD patients and the patient's body mass index.

Conclusion: Based on the results of the analysis of the relationship between the evaluation of hemodialysis patients at RS Dik Pusdikkes Kodiklat AD, 9 respondents had a poor diet with a body mass index in the lean category of 6 people $(66.7 \%)$ and the normal category of 3 people $(33.3 \%)$. And 11 respondents have a good diet relationship with body mass index in the thin category of 2 people $(40.0 \%)$ and the normal category of 12 people $(60 \%)$.
\end{abstract}

Keywords: body mass index, dietary habit.

Editor: Wk

Hak Cipta:

(C2021 Artikel ini memiliki akses terbuka dan dapat didistribusikan berdasarkan ketentuan Lisensi Atribusi Creative Commons, yang memungkinkan penggunaan, distribusi, dan reproduksi yang tidak dibatasi dalam media apa pun, asalkan nama penulis dan sumber asli disertakan. Karya ini dilisensikan di bawah Lisensi Creative Commons Attribution Share Alike 4.0 Internasional. 


\section{Pendahuluan}

Ginjal mengatur keseimbangan air dalam tubuh, mengatur konsentrasi garam dalam darah, dan mengatur keseimbangan asam basa dalam darah. ${ }^{1}$ Ketika ginjal tidak bekerja dengan baik, tidak dapat mengeluarkan limbah atau kelebihan garam. Pasien membutuhkan perawatan segera. Kondisi dimana ginjal mulai berhenti bekerja dengan baik juga dikenal sebagai penyakit Chronic Kidney Disease (CKD) atau penyakit ginjal kronis adalah gagal ginjal (nefron) yang menyebabkan sisa metabolit (toksinuremik) menumpuk dalam waktu yang lama sehingga menyebabkan ginjal tidak lagi memenuhi kebutuhan sehari-hari dan menimbulkan gejala. $^{2}$

Menurut data Riset Kesehatan Dasar (Riskesdas) 2018, prevalensi CKD di Indonesia adalah 499.800 (2\%), dimana Maluku memiliki prevalensi tertinggi, dengan $4.351(0,47 \%)$ menderita CKD ${ }^{3}$. Menurut Riskesdas tahun 2013, prevalensi CKD sebesar 0,2\%, dan prevalensi tertinggi di Sulawesi Tengah sebesar 0,5\%. ${ }^{4}$ Menurut data Indonesian Renal Registry (IRR) tahun 2015, jumlah pasien CKD yang terdaftar di unit HD di Indonesia meningkat dengan laju tahunan sebesar 10\%. Prevalensi CKD diperkirakan 400 per 1 juta penduduk, dan prevalensi pasien CKD yang mendapat HD pada tahun 2015 adalah 15.424 (IIR, 2015). Menurut IRR 2016, 98\% pasien CKD menerima pengobatan HD dan $2 \%$ menerima dialisis peritoneal. Menurut data IRR 2017, jumlah pasien CKD yang mendapat HD meningkat menjadi $77.892 . .^{5}$

Beberapa peneliti telah menemukan bahwa pasien CKD menunjukkan tanda-tanda kekurangan gizi. Penyebab malnutrisi pada pasien CKD sebenarnya banyak, antara lain asupan makanan yang tidak mencukupi, hilangnya nutrisi untuk dialisat yaitu penurunan asupan protein terjadi karena proses imflamasi gagal ginjal kronik, kurangnya peningkatan katabolisme yaitu proses alami didalam tubuh untuk menghasilkan energi karena terjadi inflamasi kronis, dan stimulasi katabolik pasien HD itu sendiri. Hal ini dapat menyebabkan pasien CKD mengkonsumsi energi dan protein. Untuk asupan rendah, disebabkan karena faktor sosial ekonomi (depresi, stres, ketidaktahuan dan kemiskinan) atau karakteristik pasien. Faktor lain adalah dampak dari Tindakan HD, yang dapat menyebabkan mual dan muntah serta adanya penyakit penyerta. ${ }^{6}$ Lamanya pasien menjalani HD berpengaruh terhadap IMT. Pada pasien DM terjadi kerusakan protein otot yang lebih cepat dibandingkan pasien CKD tanpa DM. Serum albumin, kolesterol, kreatinin \& katabolisme protein yg dianggap sebagai parameter nutrisi secara signifikan lebih rendah pada pasien DM dibandingkan pasien tanpa $\mathrm{DM}^{7}$

Hasil pengambilan data awal pada 16 Juli 2021 oleh Penanggungjawab jaga di Ruangan Hemodialisa RS Dik Pusdikkes Kodiklat AD, sebelumnya peneliti mengambil penelitian ini dikarenakan ingin mengetahui ada atau tidaknya hubungan pola makan dengan indeks massa tubuh pasien, pemeriksaan yang sering dilakukan saat pasien sebelum dan sesudah melakukan tindakan hemodialisa yaitu menimbang berat badan, dikarenakan adanya beberapa pasien yang berat badan nya ada yang dibawah normal. Sehingga peneliti tertarik untuk meneliti dan jumlah sampel nya lebih banyak.

Hasil pengambilan data didapatkan bahwa rata-rata pasien yang menjalani hemodialisa sebanyak 20 orang perbulan pasien perhari. Jumlah rata-rata Tindakan hemodialisa sebanyak 661 kali setiap 1 bulan, dimana tiap pasien terjadwal menjalani hemodialisa 1-2 kali perminggu dengan durasi 4 - 5 jam sekali terapi. Berdasarkan hasil wawancara dengan 10 pasien gagal ginjal kronik di ruang hemodialisa, 5 orang mengatakan mengalami mual muntah saatmakan, 
serta lelah dan malas makan. 3 orang lainnya mengatakan mereka membosankan. Menu pepaya dan buah nya sama. Ini adalah rutinitas yang membosankan. Dua orang mengatakan mereka lebih suka makanan siap saji. Terkadang pasien akan makan makanan yang kurang bergizi dan makanan yang harus dihentikan. Sepuluh pasien penyakit ginjal kronis yang menjalani hemodialisis dan pola makan yang tidak teratur, proporsi tubuhnya berubah drastis dan membutuhkan nutrisi yang cukup.

\section{Metode}

Metode pengumpulan data penelitian ini adalah kuesioner survey. Kuesioner adalah cara untuk mengumpulkan data atau melakukan penelitian tentang topik yang umumnya melibatkan banyak kepentingan publik. Kuesioner ini dilakukan dengan cara mengedarkan daftar pertanyaan dalam bentuk tabel, dikirim ke beberapa topik dalam bentuk tertulis untuk memperoleh jawaban, informasi, jawaban, dan lain-lain. ${ }^{8}$ Kuesioner dalam penelitian ini adalah untuk pasien CKD yang menjalani hemodialisa pada Kodiklat AD di RS Dik Pusdikkes. Untuk kuesioner dilakukan uji validitas dan reabilitas instrument uji validitas menggunakan korelasi Product of Moment Pearson, dengan mengkorelasikan skor tiap item dengan skor total. Skor total adalah jumlah semua item.

Peneitian ini telah lulus uji etik di Komisi Etik Penelitian Kesehatan dengan surat keterangan nomor: 1621/Sket/KaDept/RE/STIKIM/VII/2021

\section{Hasil dan Pembahasan}

Analisis hasil penelitian menggunakan analisis univariat yaitu untuk mengetahui distribusi frekuensi tiap variabel yaitu karakteristik responden.

\section{Analisa Univariat}

Tabel 1. Distribusi berdasarkan usia responden di ruang hemodialisa di RS Dik Pusdikkes Kodiklat AD tahun 2021

\begin{tabular}{lcc}
\hline Kategori Usia & n & Persentase \\
\hline $20-25$ tahun & 1 & $5 \%$ \\
$26-35$ tahun & 7 & $35 \%$ \\
$36-45$ tahun & 5 & $25 \%$ \\
$46-55$ tahun & 4 & $20 \%$ \\
$>56$ tahun & 3 & $15 \%$ \\
\hline Total & 20 & $100 \%$ \\
\hline
\end{tabular}

Berdasarkan tabel 1 menunjukkan bahwa dari 20 orang jumlah pasien diruang perawatan hemodialisa di RS Dik Pusdikkes Kodiklat AD yang berusia 20-25 tahun sebanyak 1 orang (1\%), usia 26-35 tahun sebanyak 7 orang (35\%), usia 36-45 tahun sebanyak 5 orang $(25 \%)$, usia $46-55$ orang sebanyak 4 (20\%), usia $>56$ tahun sebanyak 3 orang (15\%).

Tabel 2. Distribusi berdasarkan jenis kelamin responden di ruang hemodialisa di RS Dik Pusdikkes Kodiklat AD tahun 2021

\begin{tabular}{lcc}
\hline Jenis Kelamin & n & Persentase \\
\hline Laki-laki & 9 & $45 \%$ \\
Perempuan & 11 & $55 \%$ \\
\hline Total & 20 & $100 \%$ \\
\hline
\end{tabular}


Berdasarkan tabel 2, menunjukkan bahwa dari 20 orang jumlah pasien diruang perawatan hemodialisa di RS Dik Pusdikkes Kodiklat AD yang berjenis kelamin laki-laki berjumlah 9 orang (45\%) dan jenis kelamin perempuan berjumlah sebanyak 11 orang (55\%).

Tabel 3. Distribusi berdasarkan pendidikan responden di ruang hemodialisa di RS Dik Pusdikkes Kodiklat AD tahun 2021

\begin{tabular}{lcc}
\hline Pendidikan & n & Persentase \\
\hline SD & 1 & $5 \%$ \\
SMA & 12 & $60 \%$ \\
D3 & 3 & $15 \%$ \\
S1 & 4 & $20 \%$ \\
\hline Total & 20 & $100 \%$ \\
\hline
\end{tabular}

Berdasarkan tabel 3, menunjukkan bahwa dari 20 orang jumlah pasien diruang perawatan hemodialisa di RS Dik Pusdikkes Kodiklat AD yang berpendidikan SD sebanyak 1 orang (5\%), pendididkan SMA sebanyak 12 orang (60\%), Pendidikan D3 sebanyak 3 orang (15\%), Pendidikan S1 sebanyak 4 orang (20\%).

Tabel 4. Distribusi berdasarkan pekerjaan responden di ruang hemodialisa di RS Pusdikkes Kodiklat AD tahun 2021.

\begin{tabular}{lcc}
\hline Pekerjaan & n & Persentase \\
\hline IRT & 10 & $50 \%$ \\
Swasta & 6 & $30 \%$ \\
PNS & 1 & $5 \%$ \\
Mahasiswa & 1 & $5 \%$ \\
Wiraswasta & 1 & $5 \%$ \\
Pensiun & 1 & $5 \%$ \\
\hline Total & 20 & $100 \%$ \\
\hline
\end{tabular}

Berdasarkan tabel 4, menunjukkan bahwa dari 20 orang jumlah pasien diruang perawatan hemodialisa di RS Dik Pusdikkes Kodiklat AD yang berkerja sebagai IRT sebanyak 10 orang $(50 \%)$, bekerja di swasta sebanyak 6 orang (30\%), PNS sebanyak 1 orang (5\%), mahasiswa sebanyak 1 orang (5\%), wiraswasta sebanyak 1 orang $(5 \%)$, dan pensiun sebanyak 1 orang $(5 \%)$.

\section{Analisa bivariat}

\section{Hubungan pola Makan Pasien CKD yang Menjalani Hemodialisa di RS Dik Pusdikkes Kodiklat AD.}

Pola makan pasien dapat digambarkan oleh tabel dibawah ini, semakin baik pola makan pasien maka skornya akan semakin besar. Pola makan pasien penderita gagal ginjal kronik yang menjalani hemodialisa memiliki skor minimum 14 dan skor maksimum 27 dengan skor rata-rata 20,75. Hal tersebut menggambarkan bahwa pola makan pasien sudah cukup baik karena skor rata-rata tidak berbeda jauh dengan skor maksimum kuesioner 28 (berdasarkan penyataan valid).

Tabel 5. Berdasarkan pola makan

\begin{tabular}{llccl}
\hline & N & Minimum & Maksimum & Rata-rata \\
\hline Pola Makan & 20 & 14 & 27 & 20,75 \\
\hline
\end{tabular}


Selanjutnya pola makan pasien dikategorikan menjadi kategori dengan pola makan baik dan pola makan kurang baik yang akan digunakan untuk analisis bivariat. Penentuan batas kategori pola makan menggunakan nilai rata-rata, jika jumlah skor pola makan> 20,75 maka pola makan baik dan jika $<20,75$ maka pola makan kurang baik.

Tabel 6. Berdasarkan pola makan kurang baik dan pola makan baik

\begin{tabular}{lcc}
\hline Pola Makan & Frekuensi & Persentase (\%) \\
\hline Pola Makan Kurang Baik & 9 & 45 \\
Pola Makan Baik & 11 & 55 \\
Total & 20 & 100 \\
\hline
\end{tabular}

Berdasarkan tabel 6 menunjukkan bahwa dari 20 orang jumlah pasien diruang perawatan hemodialisa di RS Dik Pusdikkes Kodiklat AD pola makan yang kurang baik sebanyak 9 orang (45\%) dan pola makan yang baik sebanyak 11 orang $(55 \%)$.

Indeks massa tubuh pasien yang menjalani hemodialisa di RS Dik Pusdikkes Kodiklat AD

Tabel 7. Deskripsi proporsional tubuh pasien

\begin{tabular}{llccc}
\hline \multicolumn{1}{c}{ IMT } & N & Minimum & Maksimum & Rata-rata \\
\hline Berat Badan $(\mathrm{Kg})$ & 20 & 37,5 & 62,1 & 49,7 \\
Tinggi Badan $(\mathrm{cm})$ & 20 & 150 & 170 & 157,6 \\
\hline
\end{tabular}

Berdasarkan tabel indeks massa tubuh pasien, gambaran berat badan responden memiliki berat minimum 37,5 kg, maksimum 62,1 kg, dan rata-rata 49,7 kg. Gambaran tinggi badan pasien minimum $150 \mathrm{~cm}$, paling tinggi $170 \mathrm{~cm}$, dan dengan rata-rata $157,6 \mathrm{~cm}$. Selanjutnya berdasarkan berat badan dan tinggi badan pasien dihitung nilai IMT dan dikategorikan berdasarkan kategori IMT untuk dianalisis lebih lanjut pada analisis bivariat.

Tabel 8. Berdasarkan kategori IMT

\begin{tabular}{lcc}
\hline Kategori IMT & Frekuensi & Persentase (\%) \\
\hline Kurus/kurang & 8 & 40 \\
Normal & 12 & 60 \\
Overwight & 0 & 0 \\
Obesitas & 0 & 0 \\
Total & 20 & 100 \\
\hline
\end{tabular}

Berdasarkan tabel 8 menunjukkan bahwa dari 20 orang jumlah pasien diruang perawatan hemodialisa di RS Dik Pusdikkes Kodiklat AD, kategori IMT pasien kurus sebanyak 8 orang $(40 \%)$ dan kategori normal sebanyak 12 orang $(60 \%)$.

\section{Hubungan Pola Makan Pasien CKD Berhubungan dengan indeks massa tubuh pasien yang menjalani hemodialisa di RS Dik Pusdikkes Kodiklat AD tahun 2021.}

Untuk mengetahui hubungan pola makan pasien dengan indeks massa tubuh pasien menggunakan analisis bivariat. Analisis bivariat yang dimaksud untuk mengetahui korelasi atau hubungan antara variable independent yaitu evaluasi sosialisasi standar operasional prosedur dengan variable dependen yaitu indeks massa tubuh yang menjalani hemodialisa di RS Dik Pusdikkes Kodiklat AD tahun 2021. 
Tabel 9. Berdasarkan hubungan pola makan pasien ckd dengan indeks massa tubuh pasien

\begin{tabular}{|c|c|c|c|c|c|c|c|}
\hline \multirow{3}{*}{ Pola Makan } & \multicolumn{6}{|c|}{ Indeks massa tubuh } & \multirow{3}{*}{ P-value } \\
\hline & \multicolumn{2}{|c|}{ Kurus } & \multicolumn{2}{|c|}{ Normal } & \multicolumn{2}{|c|}{ Total } & \\
\hline & $\mathrm{N}$ & $\%$ & $\mathrm{~N}$ & $\%$ & $\mathrm{~N}$ & $\%$ & \\
\hline $\begin{array}{l}\text { Pola Makan Kurang } \\
\text { Baik }\end{array}$ & 6 & 66,7 & 3 & 33,3 & 9 & 100 & \\
\hline Pola Makan Baik & 2 & 18,2 & 9 & 81,8 & 11 & 100 & 0,028 \\
\hline Total & 8 & 40,0 & 12 & 60,0 & 20 & 100 & \\
\hline
\end{tabular}

Berdasarkan tabel 9, hasil analisis hubungan evaluasi pasien hemodialisa RS Dik Pusdikkes Kodiklat AD terdapat 9 responden hubungan pola makan kurang baik dengan indeks massa tubuh kategori kurus 6 orang $(66,7 \%)$ dan kategori normal 3 Orang (33,3\%). Dan terdapat 11 responden hubungan pola makan baik dengan indeks massa tubuh kategori kurus 2 orang $(40,0 \%)$ dan kategori normal 12 orang $(60 \%)$. Hasil dari uji chi square menunjukkan bahwa nilai $\mathrm{p}$-value $(0,028)<0,05$ maka Ha diterima atau ada hubungan antara pola makan penderita ckd dengan indeks massa tubuh pasien.

\section{Kesimpulan}

Berdasarkan dari hasil penelitian diatas bahwa sebagaian besar pola makan respondennya adalah kategori baik. Dari hasil data pengukuran berat badan dan tinggi badan Sebagian besar nilai IMT respondennya adalah kategori normal dan dari hasil uji chi square menunjukan bahwa terdapat ada hubungan antara pola makan penderita ckd dengan indeks massa tubuh pasien.

\section{Konflik Kepentingan}

Peneliti menyatakan bahwa penelitian ini independen dari konflik kepentingan individu dan organisasi.

\section{Ucapan Terima Kasih}

Terimakasih kepada seluruh pihak yang telah berkontribusi membantu proses penelitian ini.

\section{Pendanaan}

Sumber pendanaan diperoleh dari peneliti.

\section{Daftar Pustaka}

1. Sitanggang TW, Anggraini D, Utami WM. HUBUNGAN ANTARA KEPATUHAN PASIEN MENJALANI GAGAL GINJAL KRONIS DI RUANG HEMODIALISA THE RELATIONSHIP BETWEEN OBEDIENCE HEMODIALYSIS THERAPY. 2021;8:129-36.

2. Dih, Sahidya C, Batam K. Jurnal Ilmiah Zona Psikologi Jurnal Ilmiah Zona Psikologi. 2019;1(2):1-11.

3. Kunci K, Fisik A, Oedem T. HUBUNGAN DIET DAN AKTIVITAS FISIK DENGAN TINGKAT. 2021;12(1):115-22.

4. Fakultas kedokteran universitas muhammadiyah surakarta 2018. 2018;

5. Angraini DI. The Different of Protein Intake Between Chronic Renal Failure Patients with Malnutrition and Not Malnutrition in Hemodialysis Unit at dr. Abdul Moeloek Hospital Bandar Lampung sering mengalami malnutrisi, inflamasi, dan observasional dengan rancangan cross pasien gagal ginjal kronik yang telah gizi kurang yang diperoleh melalui penilaian populasi Asia . Asupan protein diperoleh. 2015;2(2):163-8.

6. Sunarni E. Hubungan dukungan keluarga dengan interdialytic weight gain (idwg) pada pasien gagal ginjal kronis di unit hemodialisis rsud boyolali. 2019; 
7. Keperawatan AM, Prodi P, Sekolah DK. Diajukan sebagai salah satu syarat mendapatkan gelar Ahli Madya Keperawatan (A.Md.Kep) Pada Prodi D-III Keperawatan Sekolah Tinggi Ilmu Kesehatan Bhakti Kencana Bandung Oleh : 2019;

8. Farmasi F, Dharma US. Plagiat merupakan tindakan tidak terpuji. 2011;

9. Pralisa K, Anggrahini D, Dewi K, In M. Gambaran etiologi penyakit ginjal kronik stadium V pada pasien rawat inap di RSUD Dokter Soedarso Pontianak tahun 2017-2018 Etiologies of stage V chronic kidney diseases among hospitalized patients at Doctor Soedarso Hospital in Pontianak in 2017-2018. 2020;6(3):59-65.

10. Kronis GG. Gambaran konsep diri pasien gagal ginjal kronik yang menjalani terapi hemodialisa. 2016;1:7-12.

11. Saiful R, Malang A. Hubungan Asupan Enegi dan Protein dengan Status Gizi Berdasarkan \% LILA menurut Umur pada Pasien Chronic Kidney Disease on. 2019;3(1):15-22. Available from: http://jurnal.unimus.ac.id/index.php/JLabMed

12. Description C, Chronic O, Disease K, Hemodializing P, Pku I, Surakarta MH, et al. KRONIK YANG MENJALANI HEMODIALISIS DI RS PKU. 3:427-39.

13. Antropometri P, Berdasarkan G, Tb U, Imt DAN, Sd US, Jasmani S-P, et al. KELAS BAWAH ANTARA DATARAN TINGGI DAN DATARAN RENDAH DI KABUPATEN PROBOLINGGO ( Studi pada SDN Negororejo 1 Kecamatan Lumbang dan SDN Tongas Wetan 1 Kecamatan Tongas Kabupaten Probolinggo ) Ahmad Nurrizky *, Faridha Nurhayati Abstrak. 2003;(20):175-81.

14. Saiful R, Malang A. Hubungan Asupan Enegi dan Protein dengan Status Gizi Berdasarkan \% LILA menurut Umur pada Pasien Chronic Kidney Disease on. 2019;3(1):15-22.

15. Rijali A. Analisis Data Kualitatif Ahmad Rijali UIN Antasari Banjarmasin. 2018;17(33):81-95.

16. KUANTITATIF Imam Gunawan. 